\title{
TACTICAL ERRORS OF ON-SITE RESEARCH
}

Ostavciuc D. I., Rusnac C. P.

When studying forensic errors and gaps made during the inspection of the scene, it should be noted that judicial practice, techniques and tactics of forensic examination, taking into account the criminal law, contain a set of technical and tactical recommendations for the inspection of the scene. Their misapplication determines the appearance of forensic errors. The specificity of forensic errors made during the inspection of the scene is that they cannot be eliminated or partially eliminated, depending on the nature and time of their detection.

Symbolically called "the key to solving the problem with several unknowns", the inspection of the scene establishes the technical and tactical rules that govern the investigation of the scene, failure to comply with which leads to tactical errors that directly affect the investigation of the crime. These errors are admitted for subjective and objective reasons, by the criminal investigation body, in all stages of the investigation of the crime scene.

The study is intended to identify tactical errors committed during the investigation of the crime scene, except for the documentation stage.

The authors note that in order to reduce the number of errors committed in the investigation at the crime scene and to eliminate their causes, it is necessary to promote an objective and legal approach to the investigation activity, to forecast in advance the criminal prosecution situations at the crime scene etc. In order to minimize the number of errors committed, it is necessary to eliminate their root causes that generate them.

By following the technical, tactical and psychological recommendations for carrying out the crime scene investigation, errors can be prevented. The elimination of the causes that generate the occurrence of the errors of investigation of the crime scene is the task of any rule of law, in which legality is the most important constitutional principle.

Key words: inspection of the scene, error, forensic tactics, tactical process, investigative action.

Оставчук Д. І., Руснак К. П. Тактичні помилки під час проведення огляду місця події

У статті підкреслюється, що в процесі вивчення криміналістичних помилок $і$ прогалин, допущених під час огляду місця події, варто зазначити, що судова практика, техніка і тактика судової експер-

(c) Ostavciuc D. I., Rusnac C. P., 2021 тизи з урахуванням кримінального законодавства містять комплекс техніко-тактичних рекомендацій для проведення огляду місця події. їх неправильне застосування визначає появу криміналістичних помилок.

Специфіка криміналістичних помилок, допущених під час огляду місця події, полягає в тому, що вони не можуть бути усунені або усуваються частково, залежно від характеру і часу їх виявлення.

Будучи символічно названим «ключем до вирішення проблеми з кількома невідомими», огляд місия події встановлює техніко-тактичні правила, які регулюють дослідження місия подіï, недотримання яких призводить до тактичних помилок, що безпосередньо впливають на розслідування злочину. Ці помилки допускаються із суб'єктивних та об'єктивних причин органами кримінального переслідування на всіх етапах огляду місия подіi.

у дослідженні автори зазначають, що для зменшення кількості помилок, допущених під час огляду місия події і усунення їх причин, необхідно просувати об'єктивний і правовий підхід до розслідування, заздалегідь прогнозувати можливі наслідки, слідчі ситуації і нейтралізацію негативних факторів. Щоб звести до мінімуму кількість скоєних помилок, необхідно усунути їх першопричини, які їх викликають.

Слідуючи технічним, тактичним і психологічним рекомендаціям із проведення огляду місия події можна запобігти помилкам. Усунення причин, що породжують помилки в процесі огляду місця події, $\epsilon$ завданням будь-якої держави, в якій законність $є$ найважливішим конституційним принципом.

Ключові слова: огляд місця події, криміналістична тактика, тактичний процес, слідча дія.

Introduction. During the recent years, along with economic development, crimes have also changed. The number of crimes committed is constantly increasing, the variety of their commission is also increasing, and the methods of their commission are changing. During the commission of an offense, the perpetrator shall do his utmost to avoid the investigation of the offense, in order to oppose the resistance to the criminal prosecution body and to mislead by any means, including fraud. All this makes it difficult to investigate crimes and establish the perpetrator. 
The quality of the on-site investigation determines the correctness of the crime investigation direction, the versions submitted and the circle of persons involved in the commission of the crime (perpetrator, partner in crime, instigator, etc.).

"According to the dictionary of criminal procedure, the on-site investigation is an evidentiary procedure that consists in the detailed investigation of the place where the deed was committed, in order to know exactly the situation of the crime, to discover and fix the crime, to establish the position and the state of the material means of proof and the circumstances in which the crime was committed" [1, p. 48].

"The on-site investigation is an irreplaceable criminal investigation, because the information obtained from the on-site investigation in most cases cannot be obtained from other sources, for example, the information obtained from the removal of the footprints and hands of the offender, application traces of breaking objects" [9, p. 25-26].

Purpose of the study. This article aims to identify tactical errors committed during the investigation of the crime scene at the stage of preparation and work.

In the process of elaborating the scientific article we were guided by a system of scientific research methods, and namely: grammatical method, systemic method, method of deduction and induction, method of analysis, comparative method and many other methods. The theoreticallegal basis of the scientific article includes the normative regulations regarding the investigation of the crime scene, the procedural-criminal doctrine in the field of investigation of the crime scene. Also, in the process of elaborating this study, we took into account the practice of law enforcement bodies; we also referred to other branches of science: ethics, judicial psychology, etc.

Results obtained and discussions. Investigative errors can be committed when conducting various criminal prosecutions. In forensic science these errors are classified as [12, p. 15]: technical-forensic and tactical-forensic errors.

Technical-forensic errors are attributed to the elements of criminal prosecution actions consisting of technological operations separate from working with objects applying means, methods and procedures for working with the traces of the crime. For example, during the removal of the traces from the crime scene, in order to expose of the DNA expertise, technical means of lifting were used, with no-sterile packaging.
Tactical-forensic errors are attributed to the elements of criminal prosecution actions that represent a system of knowledge that underlies the organization and planning of criminal prosecution and determines the optimized behavior of persons who carry out procedural actions (probative proceedings), aimed at the administration of evidence in order to achieve the purpose of the criminal process, as well as to ascertain the conditions and causes that favor the commission and concealment of crimes.

In studying the forensic errors and gaps committed in the on-site investigation, it should be mentioned that judicial practice, technique and forensic tactics, taking into account the criminal procedural legislation, contains a set of technicaltactical recommendations for conducting on-site investigation. Their incorrect application determines the occurrence of forensic errors.

The specificity of the forensic errors existing in the field research consists in the fact that they cannot be eliminated or are partially eliminated, depending on the nature and time of their discovery.

Analyzing the local literature, we find that there is no complete research on the subject of errors and gaps in the on-site research. As a rule, there are some scientific papers that address only tangentially the issue under investigation. Thus, as errors are highlighted: late reporting of facts requiring on-site investigation; lack of efficiency in travelling to the place of research or travel without first preparing the necessary technical and scientific means; insufficient request from forensic working staff or specialists from other branches of activity who can support the research body in clarifying important situations; superficiality of research, ignorance of research procedures, detection and fixation of traces and other material means of proof; their improper capitalization; tactical and methodical procedural deficiencies.

Considering that "among the important activities that contribute to the achievement of the purpose of the criminal process, in order to find out the truth, is the on-site investigation, which occupies an important place in the probation process" [7, p. 175], we further aim to highlight the errors and gaps of the on-site research, focusing in particular on the stage of preparation and conduct of the on-site research. Errors and gaps in the documentation stage will be the subject of another scientific publication, which will be a continuation of this scientific article. 
Given that the content of the on-site investigation is an act of direct perception, forensic errors are determined primarily by the conscience of the prosecuting officer, his psychological processes, conditions, skills and qualities.

Being one of the first and most complicated criminal prosecution actions, the on-site investigation requires certain skills and qualities, patience, opportunity and firmness on the part of the criminal prosecution officer.

In such conditions, the representative of the criminal investigation body does not have enough time to prepare the investigation, analyzing and weighting the tactical procedures in this regard, requesting and receiving certain consultations, etc. $\mathrm{He}$ is obliged to act urgently, realizing at the same time that any admitted error will be difficult to repair, as it may result in irreparable destruction or loss of evidence. For some, this fact raises the degree of responsibility, for the less experienced it generates a state encountered in the literature under the name "fear of making mistakes". It manifests itself in excessive emotions, haste, low level of active spirit, lack of constant and precise goals and finality, confusing behavior - all this generating the inability to properly guide the actions of participants in the on-site research. At the same time, it is well known that qualified prosecuting officers, in such complex situations, act no only quickly, with opportunity, but also with a sufficient degree of concentration, constantly. Their spirit of observation is activated, as well as their intellectual activity; they properly and competently conduct the on-site investigation. In general, this category of prosecuting officers mobilizes all physical and spiritual forces [11, p. 84].

In the same vein, the author Gheorghiță $M$. mentions that the psychological background of the crime can act on the criminal investigation officer both positively and negatively. In the first case, the emotions experienced mobilize him to make every effort to achieve the goal, to carry out the on-site examination as efficiently as possible, to do everything in his power to discover the crime and the offender. Obviously, this psychological state inspires the criminal investigation officer, directs him to use all possibilities to establish the truth in the specific case. The lack of psychological training of the criminal investigation officer and of the experience in organizing and conducting the on-site examination, the inability to control his mental processes can make him fall into captivity to the psychological background of the crime.
The influence of this fund can be manifested in his inability to become free of stress or, at least to minimize it, in lack of confidence, in disorganization, confusion, indifference, apathy, indolence, incoherence of thought. The analysis of the experience of criminal prosecution shows that such psychological states are one of the causes of superficial, formal, reckless on-site examinations, with mistakes and gaps [4, p. 389-390].

Speaking of the purpose of theon-siteinvestigation, we would like to point out that more attention is paid to the process of discovering and collecting the traces of the crime, the material means of proof to establish the circumstances of the crime or other circumstances relevant to the case, but their interpretation is omitted. As a result, the criminal investigation body limits its range of information that can be used in the investigation of the crime. For example, data about:

1. The subject of the offence:

- the number of persons participating in the commission of the crime;

- their approximate age (minor, adult, elderly);

- external signs;

- health state (presence of wounds, diseases, anatomical defects, etc.);

- the habits of the persons who committed the crime;

- profession;

- certain skills he possesses;

- data describing the mental characteristics of the perpetrators (violence, caution, shyness);

- establishment of the working regime (if the criminal act took place within the enterprises) or of the life style (if the criminal act took place in the house, in the yard, apartment).

2. The object of the offence:

- the object of the attack;

- which is the direct object of the crime;

- the anatomical and mental features of the victim (if the criminal act was directed against the person);

- particularities of goods - general and individual characteristics (if the criminal act was directed against certain things).

3. The objective side of the crime:

- the time of crime's commission;

- the manner of committing the crime;

- the actions of the offenders at the place of committing the criminal act;

- the circumstances accompanying the commission of the offence;

- the consequences of the crime; 
- the causal link between the criminal actions and the consequences.

4. The subjective side of the crime:

- the crime was committed intentionally or recklessly;

- the reason and purpose of the crime (these circumstances, to a great measure, can be deduced from the traces discovered on the spot).

In the same context, we emphasize that the criminal investigation body neglect the negative circumstances. Traces found during the on-site investigation, which do not correspond to the useful mechanism for creating specific traces for such a deed, the version submitted and the explanations given by the persons heard are called "negative circumstances".

In order to exclude cases of non-detection of negative circumstances, the prosecuting officer must:

- taking into account the advanced versions, to try to explain their location and positioning, without limiting himself to fixing objects and traces;

- submitting a certain version not to limit himself to the accumulation of evidence confirming it, but to accumulate other type of information confirming other versions;

- to overlap and compare the information received from concrete persons with the real data at the crime scene;

- to use as much as possible the special skills of the specialists, obtaining as many consultations as possible from them on the committed deed.

The existence of these circumstances at the crime scene and the erroneous assessment directly influence the investigation of the crime.

Similarly, errors are made regarding the principles governing on-site research:

- Efficiency - in some cases a lot of time is lost for traveling to the crime scene, cases of conducting the investigation on the spot are allowed without starting the criminal process ${ }^{1}$.
- Unique leadership during the investigation of the crime scene - the organization and coordination of this activity from the beginning to its end is done by several people, who also replace each other.

- Organized crime scene investigation - this rule is violated, in particular, by inexperienced criminal prosecution officers who admit conducting in a chaotic manner and without a well-established order of the crime scene investigation.

- Observing the behavior of people present at the crime scene - avoid selecting emotional reactions and establishing their connection with certain moments or activities.

- Effective use of technical-scientific means the endowed technical-forensic means in the absence of forensic specialists are not used to the maximum.

Speaking about the mistakes made directly by the criminal investigation officer, from the moment of entering the service for 24 hours, we mention that:

- he is not aware with the sector he will serve and the existing operational situation;

- does not find out the composition of the operative research group (from the guard unit of the police inspectorate), which police officers will go out on calls and what is the degree of their training. If he is unfamiliar with some members of the operative group, he does not know their professional skills, in order to make the most of them later during the on-site research;

- does not check the existence of the list of specialists in different fields, which can be requested for research, indicating their addresses and telephone numbers, as well as the presence of a large-scale map (detailed plan of the served sector - sector, city, district);

- seldom checks the technical-forensic means (universal and specialized kit);

- does not check the existence of clothing for work in a contaminated environment (specialized suit, cloak, rubber boots, rubber gloves, etc.);

${ }^{1}$ The Extended Criminal College of the SCJ admitted the lawyer's appeal, with the partial quashing of the sentence of the Buiucani Court, Chișinău municipality from 05.09.2007 and the decision of Chișinău CA from 14.11.2007, with the acquittal of A.M. under the accusation of committing the crime provided by Art. 361 paragraph (2) latter a) of the Criminal Code, for the following reasons. Contrary to the provisions of Art. 118 paragraph (1) of the Criminal Procedure Code of the Republic of Moldova, at the time of conducting the on-site investigation at the home of A.M., there was not registered, as well as no concrete crime was investigated, so the criminal investigation body had no basis or right to initiate procedural actions because they cannot be exercised before the existence of the concrete crime, without the purpose of investigating and combating it. Thus, through these actions of the criminal investigation body, the provisions of Art.12 of the CPC of the RM - inviolability of the domicile, the search and investigation of the domicile not being carried out on the basis of a judicial mandate; as well as the provisions of Art.13 of the CPC of the RM - inviolability of property, the copy of the report on the collection of the goods from his domicile was not handed over to A.M. Based on these circumstances, all the evidences that were collected and administered during the on-site investigation at the home of A.M. by the criminal investigation body, these being with essential violations of criminal procedural law, expressed in violation of the constitutional rights and freedoms of participants in the trial, are illegal and inadmissible, which cannot serve as basis for the sentence of conviction according to Art.94 of the CPC of the RM (extract from the Decision of the Enlarged Criminal College of the SCJ from 01.04.2008, File No. 1ra - 350/08). 
- does not check the existence and availability of the means of transport, to find out if there is the possibility to call on the help of a mobile forensic laboratory, in case of need.

"Taken as a whole, the preparation of the research on the spot has a unitary character, each of the activities succeeding each other in a logical-operative order, on the way it is achieved and the results of one depending on the characteristics of the one that will follow. Thus, it is necessary to carry out some activities preceding the trip on the spot, following that the preparation will be finalized with the arrival of the team at the crime scene".

In our opinion, the following errors are made during the preparation stage, preceding the trip to the spot:

- ensuring an inefficient guarding of the crime scene. The police forces arriving first at the crime scene avoid the following actions:

a) delimitation of the crime scene;

b) guarding and protection of the crime scene;

c) removing the imminent danger, if possible;

d) guarding and preserving traces in order to exclude cases of destruction;

e) taking measures to detain the suspect.

At the same time, it is worth mentioning that the police forces firstly arriving at the crime scene often forget to make a report on the data below to the leader of the criminal investigation operative group (the prosecuting officer or the prosecutor) at his arrival:

a) the essence of the criminal act and the time of arrival at the crime scene;

b) the actions taken in order to put an end to the illegal act and to detain the perpetrator;

c) in case of retention of the perpetrator the place of his location;

d) the state of the victim and the location;

e) identified witnesses and their location;

f) the limits of the crime scene to be investigated;

g) the actions undertaken in order to ensure the security of the crime scene;

h) who and why changed the original ambience of the crime scene, which was the original location of the moved objects (some of this information will be welcome until the arrival of the criminal investigation body on the spot);

- the presence of other persons whose participation is necessary is not ensured from the very beginning. The problem of the participation of other persons is solved at the crime scene when the criminal investigation body faces problems that it cannot solve on its own or the law imposes the obligatory presence of specialists;

- the research body does not in all cases take the necessary and sufficient measures so that the life, health or bodily integrity of the field team is not harmed in any form;

Analyzing the preparatory activities that take place at the crime scene, we can determine the following errors:

- the time of arrival at the crime scene and completion of the action is incorrectly fixed. The operative investigation group in some situations under the influence of subjective and objective factors incorrectly fixes the time of beginning and completion of the investigation of the crime scene. In the situation when the police forces other than the operative investigation group arrive at the crime scene, which have attributions to ensure the guarding and protection of the crime scene, the time of starting the action, is also erroneously fixed;

- does not pay attention to the conditions under which the on-site research is carried out, as demonstrated by the lack of records in the minutes of the on-site research (for example, temperature, visibility, circumstances existing at the crime scene, etc.);

- the rule that recommends that during the activities of saving the lives of the victims it is indicated that the police officers should act in such a way as not to alter or destroy other traces is underestimated (form or matter, of other means of proof existing on the spot);

- the manner in which the action was taken until the arrival of the team is not permanently verified, as well as if the necessary measures have been ordered in relation to the existing situation at the crime scene;

- the investigation group arrived at the crime scene focuses on the examining the crime scene, without undertaking other activities (for example, detention of the offender on fresh traces);

- the prosecution officer does not assign tasks to each team member, or there is a vague assignment. As a result, all the activities that need to be performed are accomplished by the criminal investigation officer and specialists. Likewise, not rarely, the criminal investigation officer misidentifies the objectives of the on-site investigation and the tasks that need to be performed by the members of the operative investigation group;

- foreigners are removed from the crime scene, and in some cases the access to the criminal field of the employees of the Ministry of Internal Affairs 
and the Prosecutor's Office who are not part of the operative investigation group is accepted;

- the service dog is not used correctly.

After all the actions from the preparation stage have been completed, the on-site research stage is used, which consists of two phases: static and dynamic. With regard to the working stage, we emphasize that, in some cases, neither their consistency not the recommendations regarding the activities that need to be carried out in each phase are observed.

The activities carried out in the static phase of the research aim at ascertaining the facts, the traces and other material means of proof, without proceeding to reach or change the position in which they were discovered. Tactical errors made in the static phase are:

- the initial phase of the crime scene investigation, the persons performing this action do not always correctly assess the boundary of the crime scene investigation. Often the boundaries of research are narrowed, which makes research incomplete, reducing the number of traces and objects that can later be recognized as criminal offenses. When determining the limits of the place of the crime, the nature and topography of the land are not taken into account (open site, building, mountainous area, swampy area, etc.) which require, as appropriate, the use of certain means and techniques of research. Members of the operative investigation group forget that the purpose of the research may include:

a. the place where the investigation of the criminal act is carried out or where traces and objects have been discovered that have the signs of physical evidence;

b. premises or open place where the offender was directly present before the crime was committed (for example, where he was preparing or waiting the victim, etc.);

c. the access and refuge road of the offender from the crime scene;

d. other premises and areas where could be objects and traces related to the crime under investigation;

- incorrect establishment and marking of the access road to the crime scene. Entry into the place of the crime is done in such a way that the traces are destroyed or damaged. Before entering the place of committing the deed, from the outside of its perimeter no judicial photographs of orientation, sketch, of the main objects as well as filming are taken. Forensic specialist does not enter first into the criminal field;
- the problem referring to the initial point of investigation is not solved correctly, as a result the tactical procedure and the method of investigating the crime scene are applied incorrectly;

- subjective changes are made to the crime scene since the static phase.

After performing the activities specific to the static phase, a thorough examination of all traces and material means of evidence discovered in the investigated perimeter is carried out [6, p. 44]. Starting from that conception, in our opinion, the dynamic phase of the on-site research is characterized by the following tactical errors: it does not always describe the position, condition, location, shape and dimensions of the categories of traces that appear as obvious on the material evidence discovered.

In the context of the above, we mention that the tactical errors of conducting on-site research are determined by subjective and objective factors.

The category of subjective factors includes:

- the criminal investigation officer does not have developed the skills to use the procedures and methodology for conducting the crime scene investigation;

- the stereotypical approach of the crime scene investigation, especially, if the tactics of conducting the crime scene investigation are determined by the satisfactory practice of obtaining the desired result;

- low level of legal awareness;

- the personality traits of the person conducting the research, such as excessive self-confidence, uncertainty, "inhibition" of thinking, negligence, etc.

The category of objective factors includes:

- the research process is insufficiently technically and financially supported, which does not allow the use of the latest achievements of science and technology;

- the situation of the "information vacuum" or the significant lack of initial information, etc.

Conclusions. In order to reduce the number of errors committed in the investigation at the crime scene and to eliminate their causes, it is necessary to promote an objective and legal approach to the investigation activity, to forecast in advance the criminal prosecution situations at the crime scene and to neutralize the negative factors. In order to minimize the number of errors committed, it is necessary to eliminate their root causes that generate them.

By following the technical, tactical and psychological recommendations for carrying out 
the crime scene investigation, errors can be prevented. The elimination of the causes that generates the occurrence of errors of investigation of the crime scene is the task of any rule of law, in which legality is the most important constitutional principle.

\section{References}

1. Antoniu Gh., Volonciu N., Zaharia N., Dicționar de procedură penală. București: Științifică și Enciclopedică, 1988.

2. Codul de procedură penală al Republicii Moldova, nr. 122-XV din 14 martie 2003. În: Monitorul Oficial al Republicii Moldova, 2013, nr. 248-251.

3. Decizia Colegiului penal lărgit al CSJ din 01.04.2008, Dosarul nr. 1ra -350/08.

4. Gheorghiță M. Tratat de criminalistică. Chișinău: Tipografia centrală, 2017. În: Popa A. Unele viziuni privind bazele juridice, etice și psihologice ale cercetării la fața locului în cauzele cu infractori minori. Legea și viața, pp.30. http://www.legeasiviata.in.ua/ archive/2020/4-5/5.pdf (vizitat 01.10.2020).

5. Luchin L. Unele erori comise în cadrul cercetării locului faptei pe cazurile accidentelor rutiere. În: Anale științifice ale Academiei „Ştefan cel Mare” a MAI al Republicii Moldova. Științe socioumane, ediția a XII-a, nr. 2. https://ibn.idsi.md/sites/default/files/ imag_file/Unele\%20erori\%20comise\%20in\%20cadrul\%20 cercetarii\%20locului\%20faptei\%20pe\%20cazurile\%20 accidentelor\%20rutiere.pdf (vizitat 1.10.2020).

6. Olteanu G. I. Considerații cu privire la tactica efectuării cercetării la fața locului, Ed. AIT Laboratories, 2004.

7. Osoianu T., Orândaș V. Procedură penală, Chișinău, 2004.

8. Ostavciuc D., Odagiu lu. Tactica efectuării cercetării la fața locului. Ghide metodic pentru ofițerii de urmărire penală. Chișinău : Cartea Militară, 2020.
9. Plămădeală I., Burbulea C., Particularitățile psihologice ale cercetării la fața locului privind diferite genuri ale infracțiunii. Criminalitatea regională: probleme și perspective de prevenire și combatere, Chișinău, mai-2005.

10. Stancu Em., Manea T. Tactică criminalistică (I). Ed. Universul juri-dic. București, 2017, p. 57. În: Popa A. Unele viziuni privind bazele juridice, etice și psihologice ale cercetării la fața locului în cauzele cu infractori minori. Legea și viața. P. 28. http:// www. legeasiviata.in.ua/archive/2020/4-5/5.pdf (vizitat 01.10.2020).

11. Калугина Н.Г. Этические основы следственных действий по делам о преступлениях несовершеннолетних. Монография. ВИПК МВД России. Домодедово 2000. С. 84. În: Alina Popa. Unele viziuni privind bazele juridice, etice și psihologice ale cercetării la fața locului în cauzele cu infractori minori. Legea și viața. P. 28. http://www.legeasiviata.in.ua/ archive/2020/4-5/5.pdf (vizitat 01.10.2020).

12. Морозова Е.В. Криминалистические проблемы следственных ошибок : автореф. дис. ... канд. юрид. наук. Екатеринбург, 2004.

Ostavciuc D. I., $P h D$,

Associate Professor at the Chair of Criminal Procedure, Forensics and Information Security Academy "Stefan cel Mare" of the Ministry of the Internal Affairs of the Republic of Moldova

Rusnac C. P., PhD, Associate Professor at the Chair of Criminal Procedure, Forensics and Information Security Academy "Stefan cel Mare" of the Ministry of the Internal Affairs of the Republic of Moldova 